\title{
IRTITIE

\section{THREE-DIMENSIONAL OF CRINKLES EFFECTS USING MULTILAYER WOVEN FABRICS CONTAINING SPANDEX}

\author{
ElSayed EINashar ${ }^{1}$ and Aleksandr Smirnov ${ }^{2}$ \\ ${ }^{1}$ Faculty of Specific Education, Kafrelsheikh University, Kafrelsheikh, Egypt \\ Faculty of Specific Education, Kafrelsheikh University, \\ P.O. Box 33516, El-Geish Street, Kafrelsheikh, Egypt, e-mail: Dr_elnashar@hotmail.com \\ ${ }^{2}$ Ivanovo Polytechnical University, Russia, e-mail: ansī3a@mail.ru
}

\begin{abstract}
Development of the wrinkled fabrics depends on geometry and relaxation behavior of the multilayer woven fabrics. After bleaching and relaxation, the new shapes and sizes of crinkles were recorded. The results prove that the manner of fabric deformation during relaxation depends upon the multilayer fabrics structure. The quantities of the crinkles on the fabric are related to the float length type. Multilayer woven fabrics with longer float length show higher crinkled, and its deformation behavior is non-linear. Thus, connected deformations are closely related to the stretch potential and influence multilayer woven fabrics draping and fitting of the garment. For this purpose, we have postulated new model for the relationship between fabric geometry and stretch potential. The suggested hypotheses make it possible to predict mathematically the crinkle of multilayer woven fabrics and prediction of suitable-sett of warp and weft. The area covering value was chosen as suitable model for description of multilayer woven fabrics structure. The study was divided into two parts, the first presents the relationship between fabric geometry of the relaxation behavior whereas the second investigated the influence of multilayer woven fabrics stretch potential on the relaxation ability of bleached fabric. Three variants of cumulative parameter of a crinkle woven fabrics structure were introduced. The realistic models based on a better approach of geometry and material properties will be created in order to investigate the numerical analysis performance of the mechanical properties of crinkle woven fabrics. A correlation between calculated values of structural parameters crinkle multilayer woven fabrics values was evaluated.
\end{abstract}

Keywords: Multilayer Fabrics, Stretch, Crinkles, Relaxation, Distortion.

\section{INTRODUCTION}

Fabrics are designed to fit different project demands in order to be suitable for their end use. [17]. for a fabric constructor it is essential that the relationships between the constructional parameters of fabrics and their individual property, that should fit the desired quality, are well defined. The mechanical properties are considerable important for the fabric end use, so a lot of researches deal with them and try to define a different models [Elnashar, Chen, Jong, Reallf, Shananah, Sinoimeri, Fangning]. [18, 10, 21, 24, 25, 26, 20], crinkles in woven fabric as wrinkled from being a part of potential aesthetic interest to the fashion or mass-market garment industry can be used as a detection and response mechanism in high performance garments $[19,11]$.

The crinkle double layer woven fabrics problem can occur in warping, weaving, and finishing processes. Tension variation across the width of the warp beam could cause bow and crinkles multilayer woven fabrics at warping and weaving stage [12]. In case of sectional warping, improper slope or tension applied to each band of the warp can create the same distortion. In addition, two sides of the weaving cloth are not equally tensioned causing crinkles multilayer woven fabrics. The main cause at any step of the finishing process is the variation in running speed across the width of the fabric, which causes shear deformation. The crinkle of double fabrics have more complex construction which is not altered only by 


\section{AR'TIE

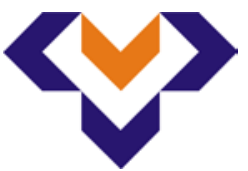 \\ Ipplied Researleches in Technics, Technologies and Bdurition \\ Journal of the Faculty of Technics and Technologies, Trakia University https://sites.google.com/a/trakia-uni.bg/artte/}

type of weave, yarn fineness and thread density, in comparison with single fabrics, but also the method of stitching [13]. The crinkle Double fabric is composed of upper and lower layers, which are woven one above the other and stitched together. Stitching these two layers of fabric together forms one of the principal features of double fabric construction. The main goal of our research was to find out if the type of weave and method of stitching have a statistically important effect on some mechanical properties of woven double fabrics in order to extend the knowledge of double woven fabric construction. The results of this research could help the constructor by developing a new fabric construction with adequate properties.[15,16],the crinkle multilayer woven fabrics by using spandex, is a generic name for rubber-like synthetic fibers comprised of at least $85 \%$ of segmented polyurethane. To improve the recovery of woven fabrics, it is now common to co-weave a small amount of spandex yarn with the companion hard yarn according the methods of stitches.

\subsection{Stitching methods of Double-layer woven fabrics [16]}

Multi-layer woven fabric consists of at least two layers, which are woven one above the other and stitched together. Double woven fabric contains two systems of warp, face and back, and two systems of weft. The fabric can be called either two-ply fabric or double fabric. Interlacing the face warp threads with the face weft threads forms upper fabric (layer), and the interlacing the back warp threads with the back weft threads forms the lower fabric (layer) of the double fabric. by stitching of the back and face fabric, double fabric can be constructed according to the following methods of stitching:

- Stitching from back to face or warp stitching, where the back warp is stitched to the face fabric;

- Stitching from face to back or weft stitching, where the face warp is stitched to the back fabric;

- Combination stitching or double stitching, where the stitching from back to face and from face to back is applied simultaneously.

- Stitching with an extra warp: the face and back fabric are stitched together by an extra warp that binds the face and back wefts.

- Stitching with an extra weft: the face and back fabric are stitched together by an extra weft that binds the face and back warps.

- Warp interchange with interlacing; where the face warp interchanges with the back warp when desired to obtain special colour effects.

- Weft interchanges with interlacing; where the back warp interchanges with the face warp when desired to obtain special colour effects.

- Chessboard stitching; where face and back warp interchange their positions in order to obtain special colour effects.

\subsection{The object of the work}

The main objective of the proposed research is to reveal the influence of the 3D structure parameters (filling yarn, fiber type, weave and type of stitches) of 3D modeling of crinkle Multi-layer woven fabric with spandex constituents on their physical and Mechanical properties (stretch and stretch recovery, thickness,) for crinkle of double-layer Woven fabric.

\section{EXPERIMENTAL}

Experiments are carried out on two group of Single and Folded core-spun yarn. First: We made core-spun yarns in Misr for spinning and weaving company EIMahala ElKoubra, Egypt according the single and folded yarn specifications - table1.

IRTIIIE Vol. 4, No. 1, 2016 ISSN 1314-8788 (print), ISSN 1314-8796 (online), doi: 10.15547/artte.2016.01.006 


\section{ARTITE Ipplied Reseircheses in Technics, Technologies and Eductition Journal of the Faculty of Technics and Technologies, Trakia University https://sites.google.com/a/trakia-uni.bg/artte/}

Table1. Specifications of Single and Folded core-spun yarn

\begin{tabular}{|c|c|c|c|c|c|c|c|c|c|}
\hline \multicolumn{4}{|c|}{ Single core-spun yarn } & \multicolumn{5}{c|}{ Folded core-spun yarn } \\
\hline Yarn type & $\begin{array}{c}\text { Blend } \\
\text { Ratio } \%\end{array}$ & $\begin{array}{c}\text { Spandex } \\
\text { denier }\end{array}$ & $\begin{array}{c}\text { Yarn } \\
\text { denier }\end{array}$ & $\begin{array}{c}\text { Final } \\
\text { denier }\end{array}$ & Yarn type & $\begin{array}{c}\text { Blend } \\
\text { Ratio \% }\end{array}$ & $\begin{array}{c}\text { Spandex } \\
\text { denier }\end{array}$ & $\begin{array}{c}\text { Yarn } \\
\text { denier }\end{array}$ & $\begin{array}{c}\text { Final } \\
\text { denier }\end{array}$ \\
\hline $\begin{array}{c}\text { Spandex+ } \\
\text { cotton }\end{array}$ & $7+93$ & Dtex 22 & $40 / 1$ & $40 / 1$ & $\begin{array}{c}2 \text { (Spandex+ } \\
\text { cotton) }\end{array}$ & $50: 50$ & Dtex 22 & $40 / 2$ & $40 / 2$ \\
\hline $\begin{array}{c}\text { Spandex+ } \\
\text { polyester }\end{array}$ & $7+93$ & Dtex 22 & $40 / 1$ & $40 / 1$ & $\begin{array}{c}2 \text { Spandex+ } \\
\text { polyester) }\end{array}$ & $50: 50$ & Dtex 22 & $40 / 2$ & $40 / 2$ \\
\hline $\begin{array}{c}\text { Spandex+ } \\
\text { (cotton+ } \\
\text { polyester) }\end{array}$ & $7+93$ & Dtex 22 & $40 / 1$ & $40 / 1$ & $\begin{array}{c}2 \text { (Spandex+ } \\
\text { (cotton+ } \\
\text { polyester)) }\end{array}$ & $50: 50$ & Dtex 22 & $40 / 2$ & $40 / 2$ \\
\hline
\end{tabular}

\subsection{Second production of double-layer woven fabrics}

Experiments are carried out on two group of fabrics structure. One group contains elastane yarn and the other group not. The weaving trials using Lycra ${ }^{\circledR}$ yarns were conducted on Sulzer Nouva weaving machine with an attachment of Sutble head jacquard, Model: JC, Made in France, with the power 2655 hook. with the following specifications; warp yarn: 30(cotton), warp density:100 ends/inch, weft density: 60 weft/inch, with using 1/1plain, 20x40 spider, in ElMahala Elkoubea companies, Egypt. In additional the fabrics were tested in Misr for spinning and weaving company, EIMahala Elkoubra, Egypt.

A groups of samples made from yarns: Type of spinning Machine: Zinser 319, Model 1986 Pinter, in spinning and weaving company, Mahala Elkoubra, Egypt. Method of spinning: core-spun yarn Spandex (denier): Dtex 22. And the source of spandex : Germany ., Type of materials: combed $100 \%$ of cotton, Giza (86), combed $100 \%$ of cotton, Giza (86) blended with polyester $(50 \%+50 \%)$, blended, cotton and Lycra ${ }^{\circledR}$ fibers as weft, but with different weight per unit area another group made from same weft , Yarn count after spinning: 40/1, 40/2 in table1. ,Twist factor :4, with 25.2 turn per inch. Type of folded machine: Savio Geminis S, with different weight per unit area for evaluation the thickness of clothing: The measurement of thickness of each of the trials woven fabrics has been carried out according to the A.S.T.M standard [3]. With two groups of woven fabrics structures; first group (upper layer plain weave 1/1, lower layer plain weave 1/1, and Satin weave 5 for stitch), second group (upper layer spider weave, lower layer plain weave 1/1, and Satin weave 5 for stitch). By using the eight Stitching methods of multilayer woven fabrics.

The tests have been carried out for textiles research labs (Chemicals Division) The National Institute, Pyramid Street, Giza, Egypt.

UPF: Resistance radiations of ultraviolet, according ASTM D 6603 - 10 Standard Guide for Labeling of UV- Protective Textiles [5],Ultraviolet Protection Factor (UPF), by using the Spectrophotometer. And Abrasion Resistance; according the ASTM D 3885 - Standard Test Method for Abrasion Resistance of Textile Fabrics (Flexing and Abrasion Method) [4], by using the RUBTESTER.

- ASTM D737- 04(2008) Standard Test Method for Air Permeability of Textile Fabrics [9]. By using Electronic Air Permeability Tester - Type FX 3300,

- ASTM D5035 - 06(2008) Standard Test Method for Breaking Force and Elongation of Textile Fabrics (Strip Method)[8], H5KT SDL ATLAS.

- The Stiffness, weight, and Thickness tests have been carried out for textiles research labs, in faculty of Specific Education, Kafrelsheikh University, Egypt. ASTM D 1388 - Standard test method for stiffness of fabrics. [2], ASTM D3776 / D3776M - 09a Standard Test Method for Mass per Unit Area (weight) of Fabric [7, 6], by using EINashar Digital Tests Methods for weight, durability, stuffiness, strength and elongation for fabrics in figure 1.

- ASTM D1777 - 96(2007) Standard Test Method for Thickness of Textile Materials [6], by using EINashar Digital Thickness Test Methods in figure 2. 


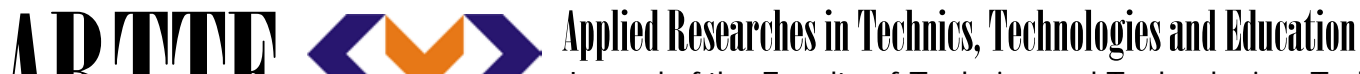 Journal of the Faculty of Technics and Technologies, Trakia University https://sites.google.com/a/trakia-uni.bg/artte/}

Invention title: EINashar Digital Tests Method for Weight, Durability, Stuffiness, Strength and Date of Rocor Fabrics

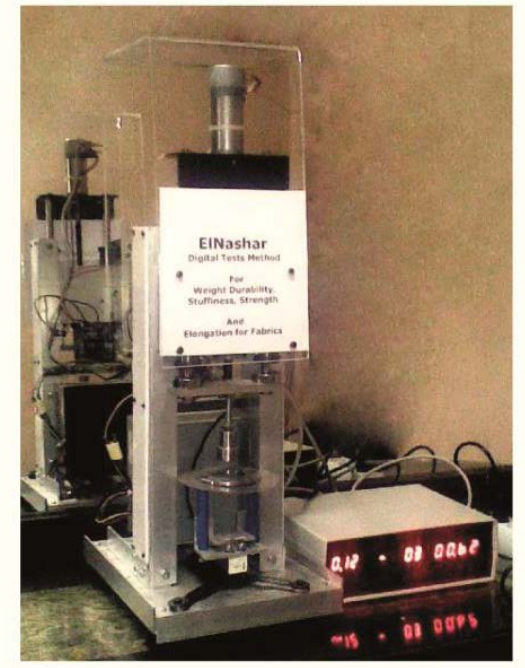

EINashar Digital Tests Method for Weight, Durability, Stuffiness, Strength and Elongation for Fabrics

Figure 1. EINashar Digital

weight, Durability, Stuffiness, Strength and

Elongation for tests methods for fabrics

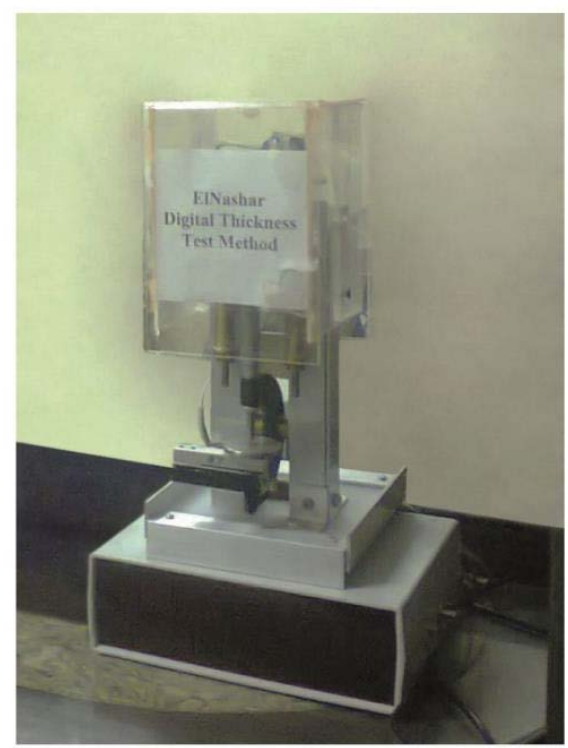

EINashar Digital Thickness Test Method

Figure 2. EINashar Digital thickness test methods

\section{RESULTS AND DISCUSSIONS}

Bulky crinkles factors: In multi-layer woven fabrics bulky crinkles in the fabrics occur as a result of change in the levels of the surface cloth in places to become three-dimensional differ in appearance from the rest of the surface of the fabric, which contributes to the type and format of the interlacing threads "woven structures" as well as the quality of the coherence and the exchange of threads among cloth layers. It has been exploring the possibility of using threads weft have spandex to produce three-dimensional effects. Threedimensional effects have been developed through designs woven fabrics with different degrees of intensity. Different degrees of intensity caused shrinkage of various on removing the cloth of the" loom, washing in relax. Constructivist free installation fabric such as cooled contraction caused the highest compared with the arbitrator fabric such as masters of 1/1. Different deflation cause of parts of the design rises in vertical direction on the surface of cloth.

The use of threads that contain spandex integrated with different fabrics and using different combinations of woven fabric structures to the production of three-dimensional effects "bulky crinkle ", Note that washed under tension light or non-existent - without the need to heat or chemical treatment or mechanical methods such as that used to produce effects of wrinkles.

Development of the fabrics curls depends on the construction of engineering and behavior of relax woven fabrics. After Whitening and relaxation were registered wrinkles new forms and sizes. The results prove that the way in which distorted the cloth during constructivist relax depends on the installation. Quantities of crumple fabrics linked to type the floated length, fabrics with floated longer appear higher crimp, distorted by non-linear behavior. Thus, the distortions are closely linked to rate durability rubber cloth robes and appropriate. For this purpose, we assume that a new model of the relationship between the installation engineering rubber rate. Realistic models are based on the best replace the geometrical

IRITIE Vol. 4, No. 1, 2016 ISSN 1314-8788 (print), ISSN 1314-8796 (online), doi: 10.15547/artte.2016.01.006 


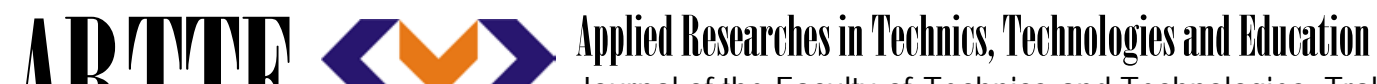 Journal of the Faculty of Technics and Technologies, Trakia University https://sites.google.com/a/trakia-uni.bg/artte/}

characteristics of raw material which can be implemented in order to achieve Numerical analysis mechanical specificity fabrics woven discoloration. Processing plays an important role in the final characteristics elastane fabrics containing spandex ,termination cause slack fabric of tension, which happen to him during the curling cloth .If the installation fabric constructivist allows deflation, mostly cloth is shrinking as a result of reaction spandex component, if required, the high rubber cloth must be designed low level to the average of the tension. The relations between the rates of rubber cloth, installation, constructivist learning to give crimp spandex type, allowing design requirements specialized rubber products to suit the performance of final use. As the following factors:

1. Types of woven fabric structures;

2. Stitching methods of multilayer woven fabrics

3. Fabric structures.

4. Types of multi-layer woven fabrics.

5. Type of materials

6. Processor thermal on fabrics (wet, dray).

7. Chemical processors on Fabrics:

The dimensions of the woven sample before and after wet relaxation were used to calculate the stretch potential using equations 1 and 2. Maximum stretch potential \% in length (warp) direction [22],

$$
S P_{L, \max }=\frac{L_{\text {on-loom }}-L_{\text {relaxed }}}{L_{\text {on-loom }}} \times 100
$$

Maximum stretch potential \% in width (weft) direction,

$$
S P_{W, \max }=\frac{W_{\text {on-loom }}-W_{\text {relaxed }}}{W_{\text {on-loom }}} \times 100
$$

Here $L_{\text {on-loom }}$ and $W_{\text {on-loom }}$ are the length and width of the on-loom fabric. $L_{\text {relaxed }}$ and $W_{\text {relaxed }}$ are length and width of the woven samples after wet relaxation. The target stretch dimensions at which the woven samples would be heat-set were calculated using equation 3 . [22] Fabric dimensions at target stretch of $y \%$

$$
W_{y \%}=W_{\text {on-loom }}-\frac{\left(y * W_{\text {on-loom }}\right)}{100}
$$

We can calculate the bulking potential according the following Equation:

$$
\mathrm{FTB}=1 / \frac{W R_{\text {relaxed }} * S P_{W, \text { max }}}{W R_{\text {on-loom }} * T}
$$

$$
\begin{array}{ll}
\mathrm{BP} & =\text { bulking potential } \\
W R_{\text {relaxed }} & =\text { width repeat of clothe after relaxation } \\
W R_{\text {on-loom }} & =\text { width repeat of woven fabric on loom } \\
S P_{W, \max } & =\text { stretch potential } \\
\mathrm{T} & =\text { clothe thickness }
\end{array}
$$


Table 2. Specifications of potential of )Bulking \& crinkles)

\begin{tabular}{|c|c|c|c|c|c|c|c|c|c|c|c|c|c|c|c|c|}
\hline \multirow{3}{*}{$\begin{array}{c}\text { Woven Fabric } \\
\text { Structures }\end{array}$} & \multicolumn{16}{|c|}{ Potential of (Bulking\& Crinkles) } \\
\hline & \multicolumn{2}{|c|}{$\begin{array}{c}\text { Specimen } \\
1\end{array}$} & \multicolumn{2}{|c|}{$\begin{array}{c}\text { Specimen } \\
2\end{array}$} & \multicolumn{2}{|c|}{$\begin{array}{c}\text { Specimen } \\
3\end{array}$} & \multicolumn{2}{|c|}{$\begin{array}{c}\text { Specimen } \\
4\end{array}$} & \multicolumn{2}{|c|}{$\begin{array}{c}\text { Specimen } \\
5\end{array}$} & \multicolumn{2}{|c|}{$\begin{array}{l}\text { Specimen } \\
6\end{array}$} & \multicolumn{2}{|c|}{$\begin{array}{c}\text { Specimen } \\
7\end{array}$} & \multicolumn{2}{|c|}{$\begin{array}{c}\text { Specimen } \\
8\end{array}$} \\
\hline & $\mathrm{BP}$ & $\mathrm{CP}$ & $\mathrm{BP}$ & $\mathrm{CP}$ & $\mathrm{BP}$ & $\mathrm{CP}$ & $\mathrm{BP}$ & $\mathrm{CP}$ & $\mathrm{BP}$ & $\mathrm{CP}$ & $\mathrm{BP}$ & $\mathrm{CP}$ & $\mathrm{BP}$ & $\mathrm{CP}$ & $\mathrm{BP}$ & $\mathrm{CP}$ \\
\hline \multicolumn{17}{|c|}{ First group of fabric Structures } \\
\hline $\begin{array}{l}\text { Upper cloth: Weave } 1 / 1 \text {, } \\
\text { Lower cloth : Weave } 1 / 1 \text {, } \\
\text { Weave of Stitch : satin } \\
\text { weave } 5 \\
\text { [Methods of Stitches }(4,5)]\end{array}$ & 1,07 & 15,6 & 1,14 & 5,8 & 1,19 & 6,3 & 1,6 & 8,02 & 1,6 & $\begin{array}{l}10 \\
8,6\end{array}$ & $\begin{array}{c}1,6 \\
0\end{array}$ & 106,9 & 1,6 & $\begin{array}{l}10 \\
6,8\end{array}$ & 1,4 & 94,2 \\
\hline Width of clothe $/ \mathrm{Cm}$ & \multicolumn{2}{|c|}{242} & \multicolumn{2}{|c|}{199} & \multicolumn{2}{|c|}{201} & \multicolumn{2}{|c|}{197} & \multicolumn{2}{|c|}{256} & \multicolumn{2}{|c|}{256} & \multicolumn{2}{|c|}{256} & \multicolumn{2}{|c|}{256} \\
\hline Width of repeated on loom & \multicolumn{2}{|c|}{260} & \multicolumn{2}{|c|}{260} & \multicolumn{2}{|c|}{260} & \multicolumn{2}{|c|}{260} & \multicolumn{2}{|c|}{260} & \multicolumn{2}{|c|}{260} & \multicolumn{2}{|c|}{260} & \multicolumn{2}{|c|}{260} \\
\hline Stretch Potential & \multicolumn{2}{|c|}{0,069} & \multicolumn{2}{|c|}{0,234} & \multicolumn{2}{|c|}{0,226} & \multicolumn{2}{|c|}{0,242} & & 15 & \multicolumn{2}{|c|}{0,015} & \multicolumn{2}{|c|}{0,015} & \multicolumn{2}{|c|}{0,015} \\
\hline Second group of fabri & truc & ires & & & & & & & & & & & & & & \\
\hline $\begin{array}{l}\text { Upper cloth: spider weave, } \\
\text { Lower cloth : Weave } 1 / 1 \text {, } \\
\text { Weave of Stitch : satin } \\
\text { weave5 } \\
\text { [Methods of Stitches }(4,5)]\end{array}$ & 1,28 & $\begin{array}{c}19,7 \\
9\end{array}$ & 1,6 & 6,2 & 1,61 & 6,4 & $\begin{array}{c}1,5 \\
0\end{array}$ & 6,09 & $\begin{array}{c}1,9 \\
4\end{array}$ & $\begin{array}{c}74, \\
7\end{array}$ & $\begin{array}{c}1,8 \\
7\end{array}$ & 71,9 & 1,91 & $\begin{array}{c}63, \\
7\end{array}$ & $\begin{array}{c}1,8 \\
4\end{array}$ & 70,8 \\
\hline Width of clothe / Cm & & & 17 & & 18 & & & 33 & & & & 53 & & & & 53 \\
\hline Width of repeated on loom & & & 26 & & 26 & & & 60 & & & & 60 & & & & 60 \\
\hline Stretch Potential & & & 0,3 & & 0,3 & & & 96 & & & & 26 & & & & 026 \\
\hline
\end{tabular}

BP: Bulking Potential, CP: Crinkles Potential

The weft of cotton for the two layers of control specimen (2 single: 1 folded).

Table 3. Properties of Bulking \& Crinkles of double-layer woven fabrics

\begin{tabular}{|c|c|c|c|c|c|c|c|c|c|c|c|c|c|c|c|c|}
\hline \multirow{3}{*}{$\begin{array}{l}\text { Woven Fabric } \\
\text { Structures }\end{array}$} & \multicolumn{16}{|c|}{ Properties of Bulking\& Crinkles of double-layer woven fabrics } \\
\hline & \multicolumn{2}{|c|}{$\begin{array}{c}\text { Specimen } \\
1\end{array}$} & \multicolumn{2}{|c|}{$\begin{array}{l}\text { Specimen } \\
2\end{array}$} & \multicolumn{2}{|c|}{$\begin{array}{c}\text { Specimen } \\
3\end{array}$} & \multicolumn{2}{|c|}{$\begin{array}{c}\text { Specimen } \\
4\end{array}$} & \multicolumn{2}{|c|}{$\begin{array}{l}\text { Specimen } \\
5\end{array}$} & \multicolumn{2}{|c|}{$\begin{array}{l}\text { Specimen } \\
6\end{array}$} & \multicolumn{2}{|c|}{$\begin{array}{c}\text { Specimen } \\
7\end{array}$} & \multicolumn{2}{|c|}{$\begin{array}{c}\text { Specimen } \\
8\end{array}$} \\
\hline & $\mathrm{BP}$ & $\mathrm{CP}$ & $\mathrm{BP}$ & $\mathrm{CP}$ & $\mathrm{BP}$ & $\mathrm{CP}$ & $\mathrm{BP}$ & $\mathrm{CP}$ & $\mathrm{BP}$ & $\mathrm{CP}$ & $\mathrm{BP}$ & $\mathrm{CP}$ & $\mathrm{BP}$ & $\mathrm{CP}$ & $\mathrm{BP}$ & $\mathrm{CP}$ \\
\hline \multicolumn{17}{|c|}{ First group of fabric Structures } \\
\hline & 1,07 & 15,6 & $\overline{1,14}$ & 5,8 & 1,19 & 6,3 & 1,6 & 8,02 & 1,6 & 108,6 & 1,6 & 106,9 & 1,6 & 106,8 & 1,4 & 94,2 \\
\hline Strength (newton) & \multicolumn{2}{|c|}{242} & \multicolumn{2}{|c|}{199} & \multicolumn{2}{|c|}{201} & \multicolumn{2}{|c|}{$\frac{1}{197}$} & \multicolumn{2}{|c|}{256} & \multicolumn{2}{|c|}{$\frac{1}{256}$} & \multicolumn{2}{|c|}{256} & \multicolumn{2}{|c|}{256} \\
\hline Elongation(mm) & \multicolumn{2}{|c|}{260} & \multicolumn{2}{|c|}{260} & \multicolumn{2}{|c|}{260} & \multicolumn{2}{|c|}{260} & \multicolumn{2}{|c|}{260} & \multicolumn{2}{|c|}{260} & \multicolumn{2}{|c|}{260} & \multicolumn{2}{|c|}{260} \\
\hline $\begin{array}{l}\text { Air permeability } \\
\left(\mathrm{Cm}^{3} / \mathrm{Cm}^{2} . \mathrm{S}\right)\end{array}$ & \multicolumn{2}{|c|}{68,66} & \multicolumn{2}{|c|}{46,66} & & & & 5 & & 3 & & 26 & & 7,66 & & 33 \\
\hline Thickness (mm) & & & & & & & & 18 & & 63 & & 605 & & 603 & & 114 \\
\hline Wight (grams $\left./ \mathrm{m}^{2}\right)$ & & & & & & & & 5,6 & & 39 & & 4,3 & & 5,6 & & 4,6 \\
\hline Stiffness (mg.cm) & & & & & & & & 9 & & 4,6 & & 1,5 & & 6,7 & & 0,3 \\
\hline $\begin{array}{l}\text { Aborigine resistance } \\
\text { (cycle) }\end{array}$ & & & & & & & & 4,6 & & 8,3 & & 60 & & 35,6 & & 60 \\
\hline UPF & & & & & & & & 5 & & 5,3 & & 4,6 & & 57 & & 7,9 \\
\hline Second group of fal & c Stru & ures & & & & & & & & & & & & & & \\
\hline & 1,28 & 19,79 & 1,6 & 6,2 & 1,61 & $\overline{6,4}$ & 1,5 & 6,09 & 1,9 & 74,7 & 1,8 & 71,9 & 1,91 & 63,7 & 1,8 & 70,8 \\
\hline Strength (newton) & & & & & & & & 33 & & 53 & & 53 & & 52 & & 53 \\
\hline Elongation(mm) & & & & & & & & 50 & & 50 & & 60 & & 60 & & 50 \\
\hline $\begin{array}{l}\text { Air permeability } \\
\left(\mathrm{Cm}^{3} / \mathrm{Cm}^{2} . \mathrm{S}\right)\end{array}$ & & & & & & & & 66 & & 32 & & 37 & & 5 & & 5 \\
\hline Thickness (mm) & & & & & & & & 5 & & 94 & & 87 & & ,91 & & 84 \\
\hline Wight (grams $\left./ \mathrm{m}^{2}\right)$ & & & & & & & & 9 & & 6,6 & & 3,3 & & 77 & & 7,3 \\
\hline Stiffness (mg.cm) & & & & & & & &, 8 & & 3,2 & & 0,7 & & 36,2 & & 5,9 \\
\hline $\begin{array}{l}\text { aborigine resistance } \\
\text { (cycle) }\end{array}$ & & & & & & & & 5,3 & & 1,3 & & 47 & & 59 & & 30 \\
\hline UPF & & & & & & & & 3 & & $\overline{3,9}$ & & 9,2 & & $\overline{8,5}$ & & 1,3 \\
\hline
\end{tabular}

The following are the results of quality using radar maps of the samples control in combination histological first and every form represents properties that have been measured practical experiments which evaluate (tensile strength and elongation, air permeability and abrasion resistance, Stiffness and resistance to ultraviolet radiation) and shows every form in the shaded properties scale space and determines that order of preference in specimen (1, $2,3)$. Then the sample number (1) using a fourth method of stitch.

IRTIII Vol. 4, No. 1, 2016 ISSN 1314-8788 (print), ISSN 1314-8796 (online), doi: 10.15547/artte.2016.01.006 

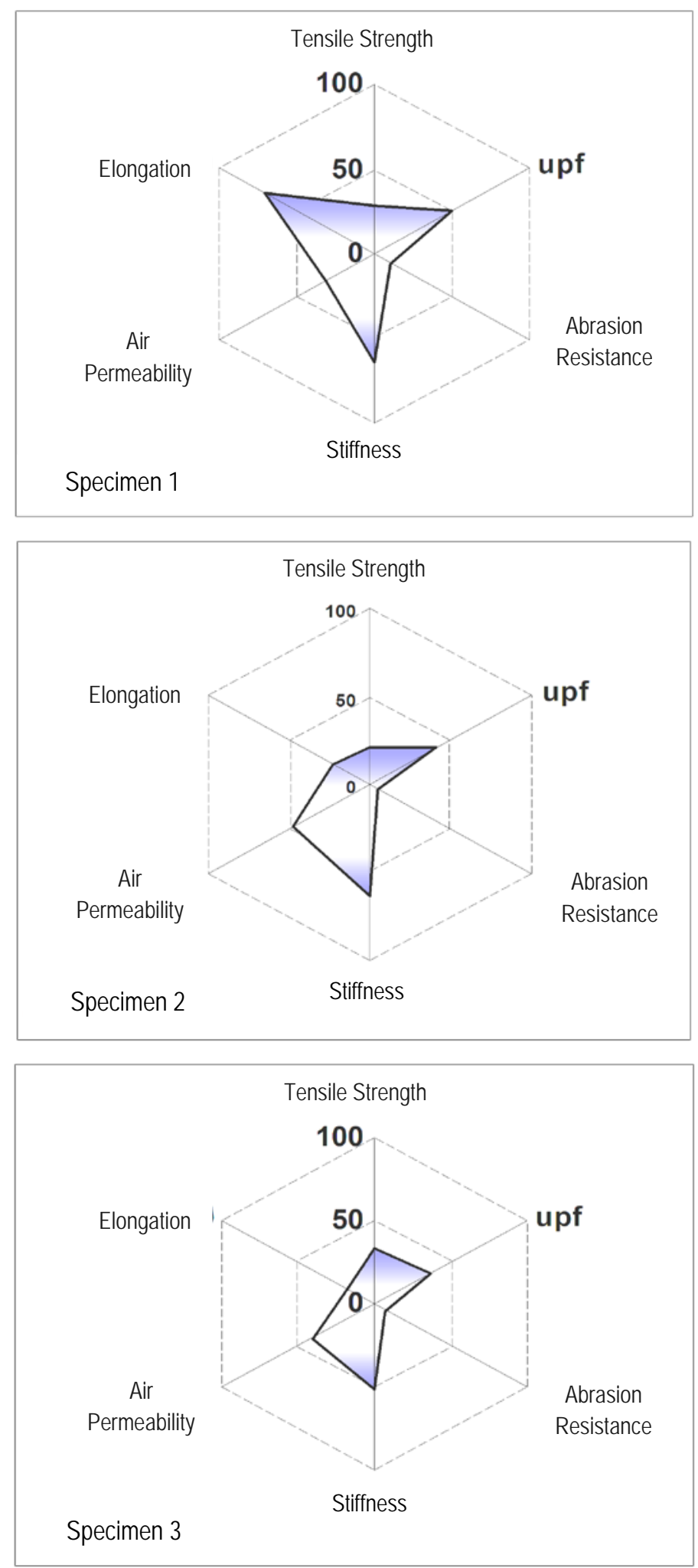

Figure 3. Specimen $(1,2,3)$ : shows the results of using quality radar maps of the first group of fabric structures

IRTIIE Vol. 4, No. 1, 2016 ISSN 1314-8788 (print), ISSN 1314-8796 (online), doi: 10.15547/artte.2016.01.006 

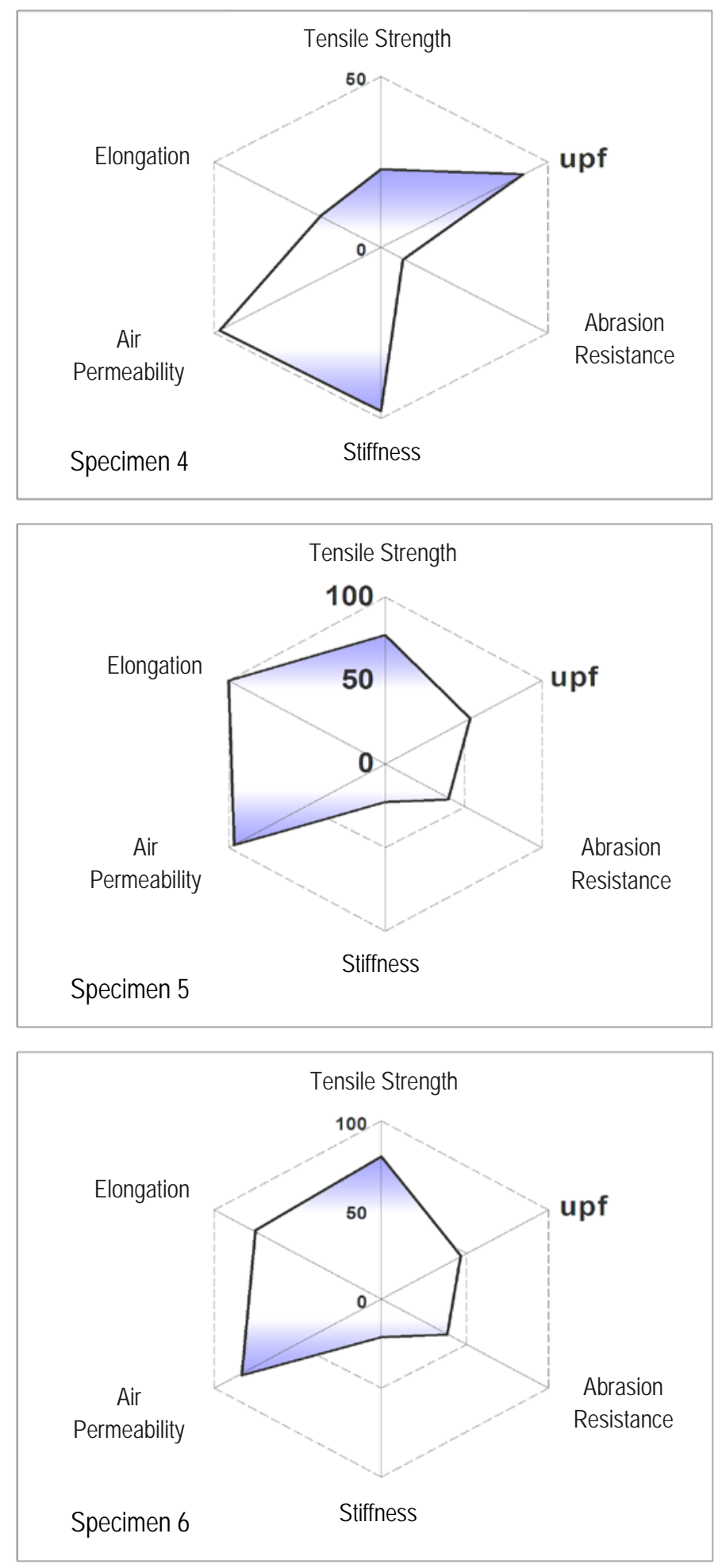

Figure 4.

Specimen $(4,5,6)$ : shows the results of using quality radar maps of the first group of fabric structures

IRITIE Vol. 4, No. 1, 2016 ISSN 1314-8788 (print), ISSN 1314-8796 (online), doi: 10.15547/artte.2016.01.006 


\section{ARITIE}

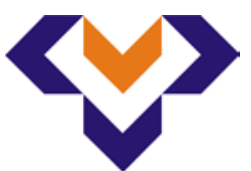

From previous results, we find that the best samples containing spandex in the composition of textile first, a plain $1 / 1$ of the two layers and texture of satin weave 5 is the Specimen (8) using a weft of spandex encased by a thread mixture (cotton + polyester) using fifth type of cohesion, a cohesion added weft redundant, followed by the sample number (6) using a weft of Spandex covered with cotton using fifth type of cohesion, a cohesion by adding extra weft, then the sample number (7) using a weft of spandex encased polyester using a fifth type of cohesion, a cohesion by adding extra weft, any that there is a clear preference for the fifth type of cohesion in this Textile installation.
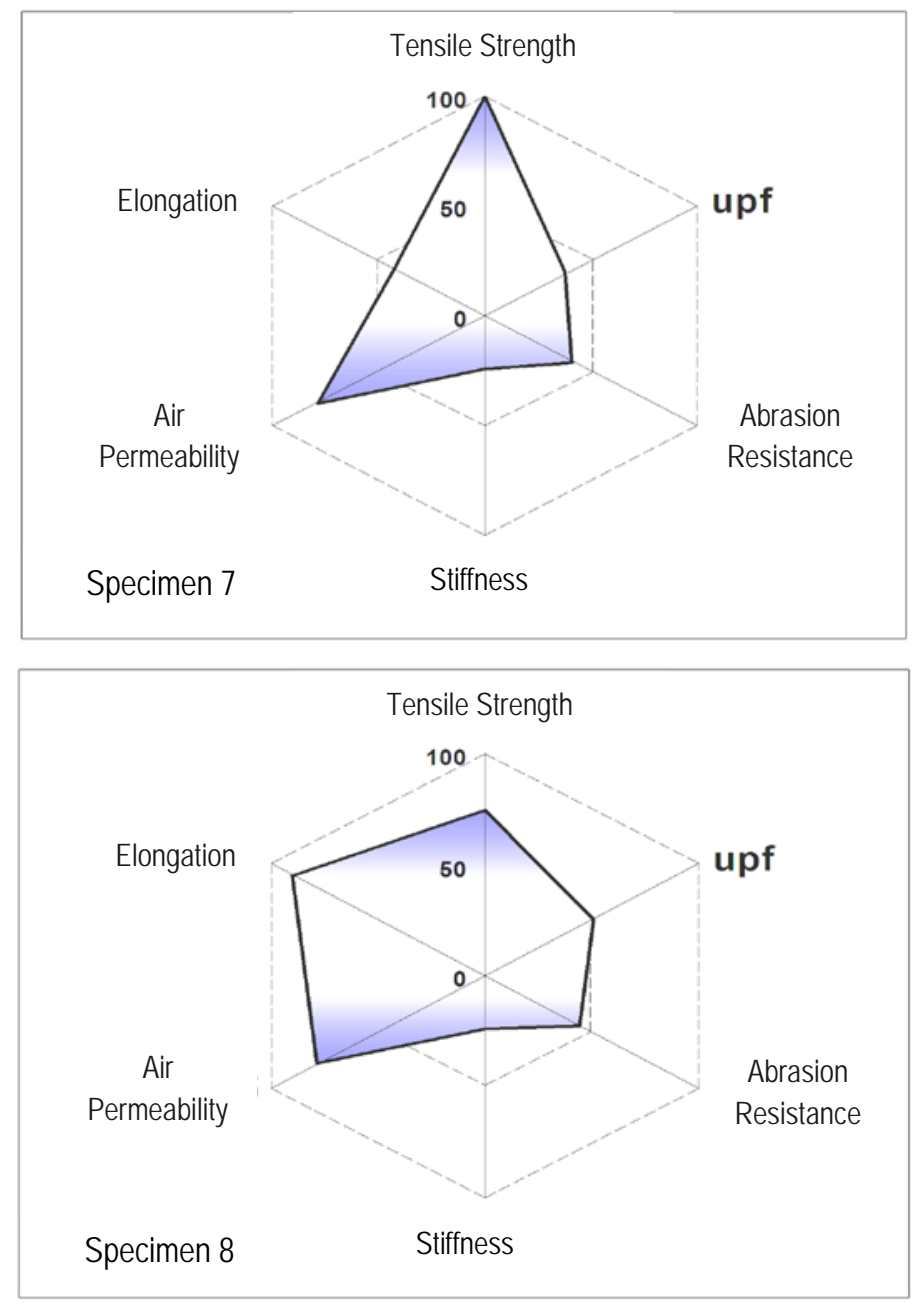

Figure 5. Specimen $(7,8)$ : shows the results of using quality radar maps of the first group of fabric structures

The following are the results of quality using radar maps of the samples officer in the composition of textile second and every form represents properties that have been measured practical experiments which evaluate (tensile strength and elongation, air permeability and abrasion resistance, stiffness and resistance to ultraviolet radiation) and shows every form in the shaded properties scale space and determines that order of preference in specimen ( 1 , 2,3 ). Followed by the specimen (5) using a fifth method of stitch, a cohesion by adding extra weft. 

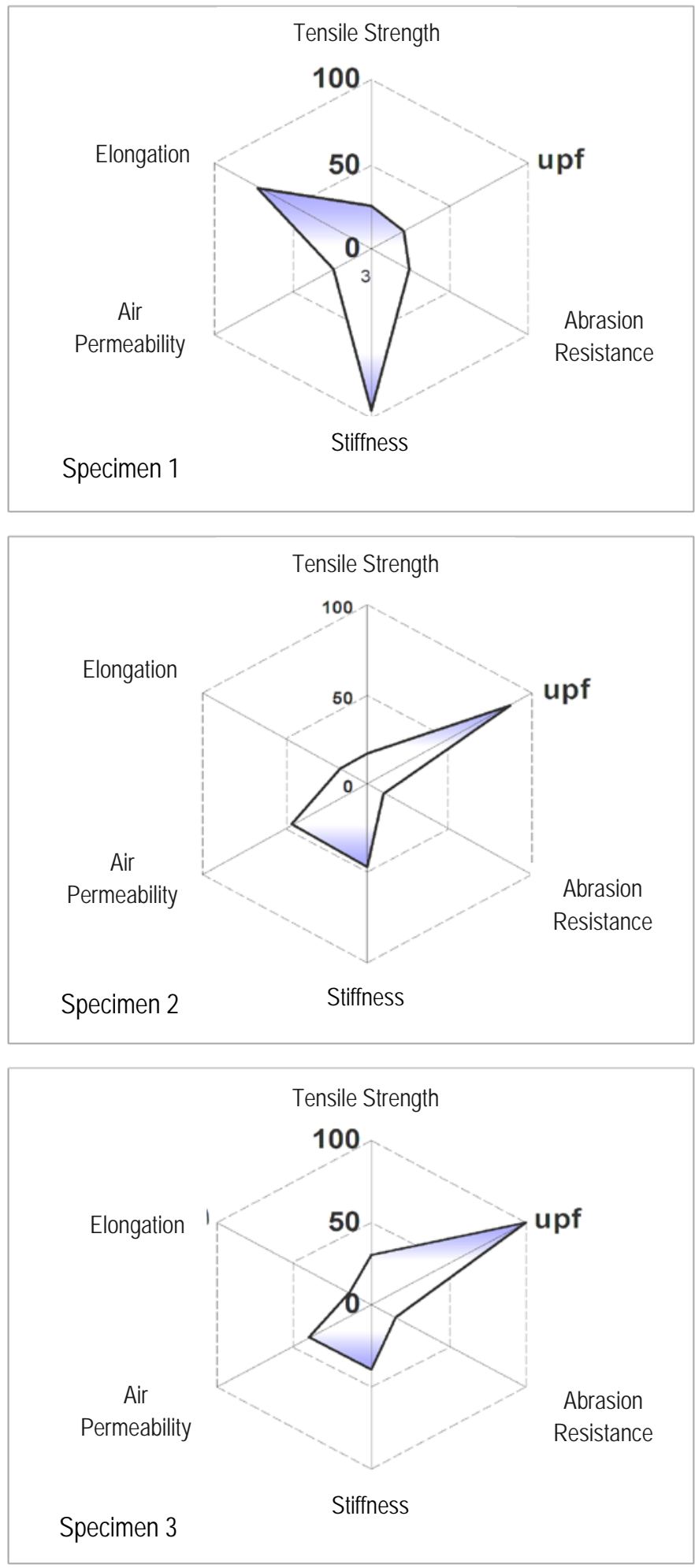

Figure 6 . Specimen $(1,2,3)$ : shows the results of using quality radar maps of the second of fabric structures

IRTIIE Vol. 4, No. 1, 2016 ISSN 1314-8788 (print), ISSN 1314-8796 (online), doi: 10.15547/artte.2016.01.006 

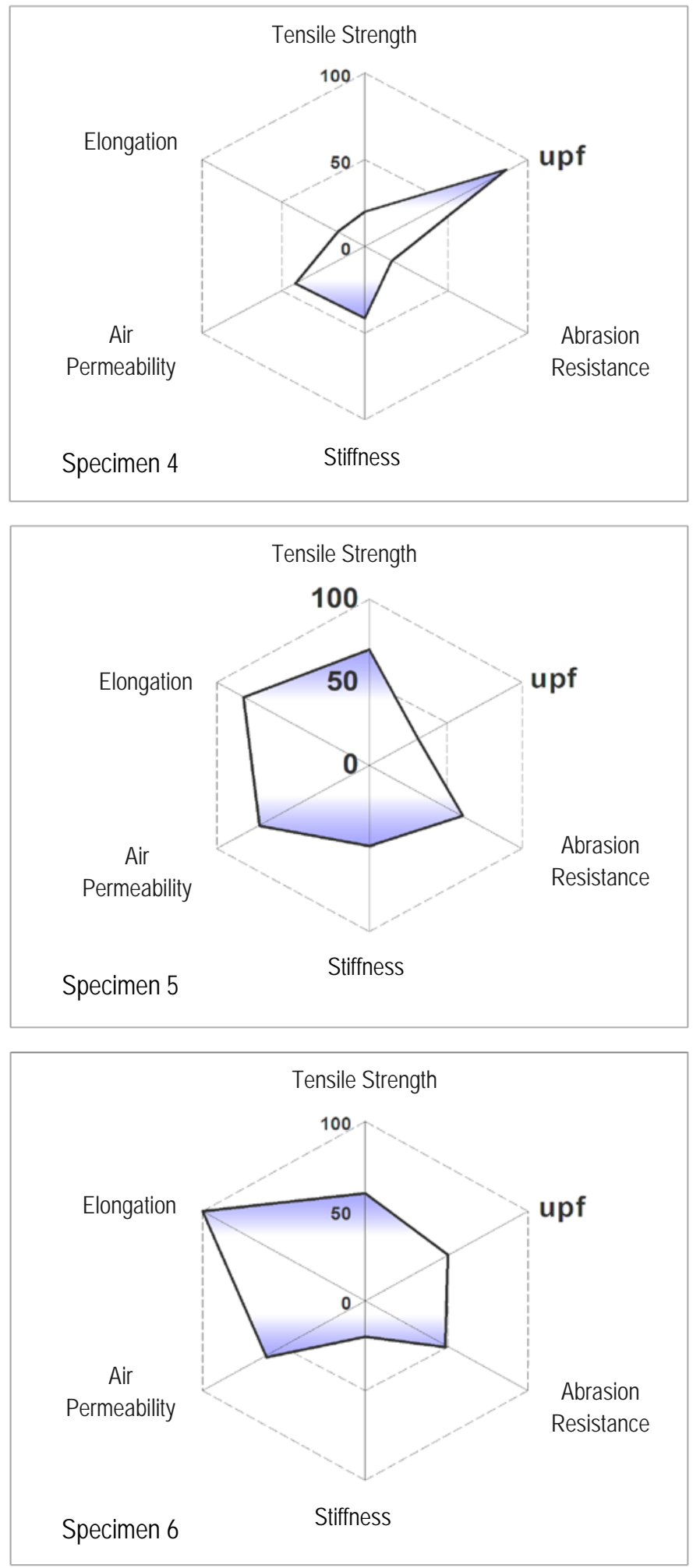

Figure 7 . Specimen $(4,5,6)$ : shows the results of using quality radar maps of the second of fabric structures

IRTTIE Vol. 4, No. 1, 2016 ISSN 1314-8788 (print), ISSN 1314-8796 (online), doi: 10.15547/artte.2016.01.006 


\section{ARITIE}

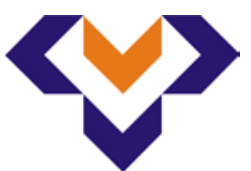

From previous results, we find that the best samples containing spandex in the composition of textile second which is the top layer spider web and lower plain weave 1/1 and the fabric of cohesion Atlas 5 is the specimen (6) using a weft of spandex covered with cotton using fifth type of cohesion, a cohesion by adding extra weft , followed by the specimen(8) using a weft thread of Spandex encased mixture (cotton + polyester) using fifth type of cohesion, a cohesion by adding extra weft, Then the specimen(1)using a weft of spandex covered with cotton using a third method of stitch, a common (warp and weft), then the specimen (7) using a weft of spandex encased polyester using a fifth type of cohesion, a cohesion by adding extra weft, that is, there is a clear preference for the fifth type of method stitch.
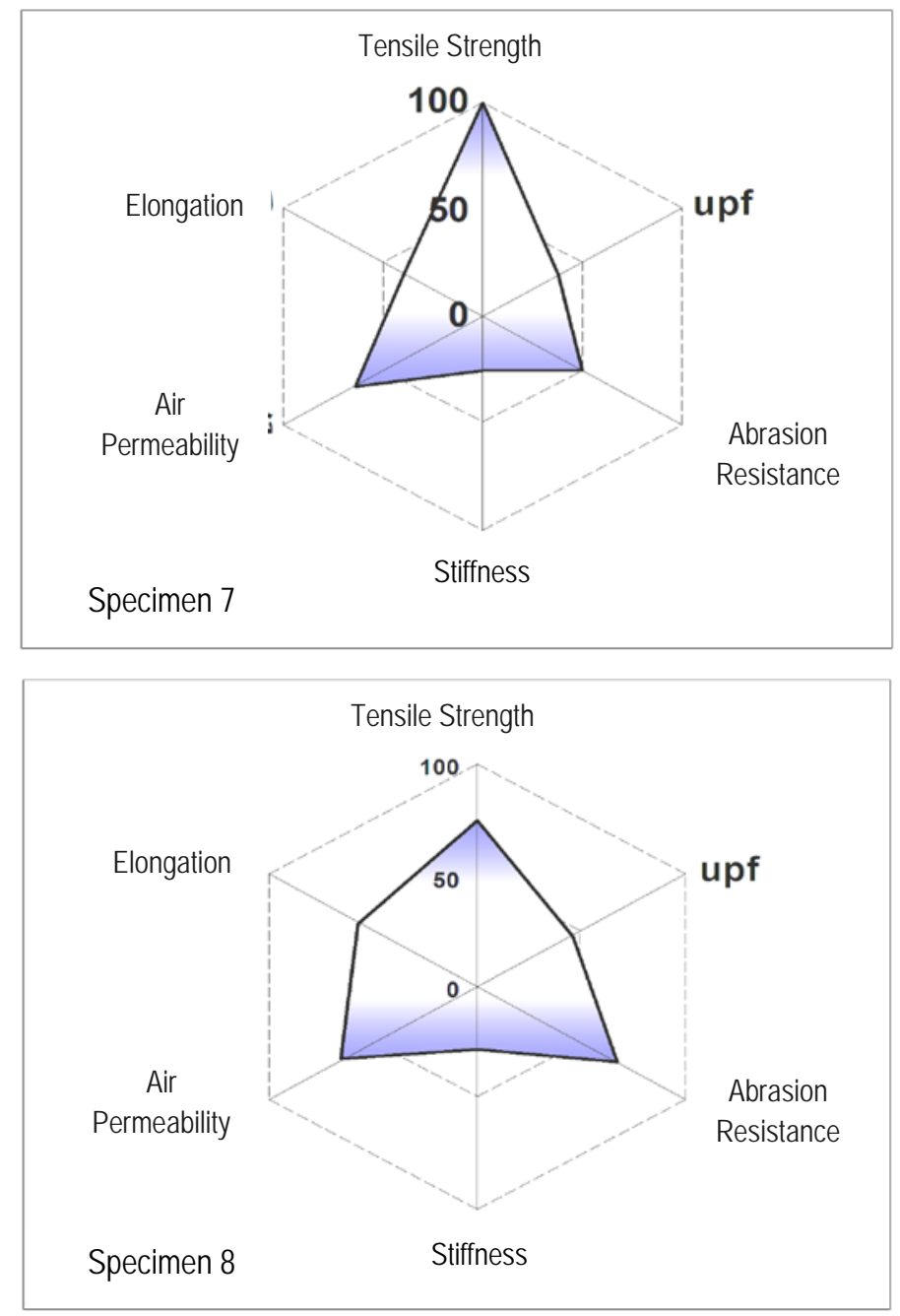

Figure 8. Specimen $(7,8)$ : shows the results of using quality radar maps of the second of fabric structures

Crinkles Potential of weave pattern development of element structures 3D woven structures can be produced on conventional (2D) weaving machines by flattening and weaving them as multi-surface, woven fabrics. After the removal of the woven semi-finished product from the machine, it is erected or shaped as desired. In general, the transformation Crinkles Potential of 3D semi-finished products into weaves-Technically producible structures can be divided into three main process steps. These are explained in the following.

IRITIE Vol. 4, No. 1, 2016 ISSN 1314-8788 (print), ISSN 1314-8796 (online), doi: 10.15547/artte.2016.01.006 


\section{AR'TIE

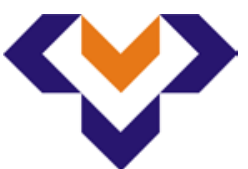 \\ Ipplied Reseirldhes in Technics, Technologies and Bductation \\ Journal of the Faculty of Technics and Technologies, Trakia University https://sites.google.com/a/trakia-uni.bg/artte/}

- Developing the desired structure: This includes the shaping of the original form into a weave-technically (woven) producible planar structure. Several development variants are possible for the same 3D structure.

- For each development variant, a number of yarn arrangement possibilities are designed, which have to be realizable by the loom. This allows the pinpointing of the most readily realizable variant. The selected development variant should be characterized by an optimized yarn orientation and subsequently excellent properties and produce ability.

- Corresponding to the selected variant, the weave patterns of the specific structure are developed, and then used to realize the desired final product on the weaving machine. With this method, numerous complexes Crinkles Potential of 3D structures can be realized using conventional loom technology without any special modules or technologies. Based on above mentioned steps,

The basic theories of design do not change when designing stretch filling fabrics. The fabric in a plain, twill weave cannot stretch until they shrink. A construction must therefore provide for shrinkage, and there must be sufficient space between ends such as spider weave. This section includes a comparison of woven fabrics produced from wefts and the arranging as horizontal stripes of weft with spandex, all the woven samples were then wet-relaxed and the relaxed dimensions of the marked squares were measured and recorded. The dimensions of the woven samples before and after wet relaxation were used to calculate crinkles potential. Several goals were established for statistical analysis of the data.

\subsection{Compact Colour Values of Crinkles Potential}

Yarn mass per length unit, threads density, stretch potential and weave determine the size and the shape of the stretch surfaces on a fabric, which are covered with warp and weft threads, stretch potential geometrical models of plain weave, satin (double cloth), plain weave (double cloth), with the warp interlacing point- $w$ and the weft interlacing point-f. colour surfaces are warp-1, weft-2 and space between threads; the diameters of the warp and weft threads, and $1 / \mathrm{gw}$ and $1 / \mathrm{gf}$ the spaces between the warp and weft threads, the size of the stretch weft and warp interlacing point surface is calculated from the geometrical model.

\subsection{Crinkles Potential in Patterns of Triangular, Rectangular and Circle}

Triangular, rectangular and circle pattern are the face of the original elements of artwork into three smaller during this all-quad woven fabrics mesh conversion, of warp and weft yarns that appears on the fabric faces, which is a function of the constructional parameters (warp and filling yarns densities, warp and filling fiber densities, warp density, pick density, weave, warp color arrangement, and weft color arrangement, the changing between two-layers). To predict contribution of each colors/weaves to the fabric surface, we considered idealized fabric geometry with the following assumptions to simplify calculations since real fabric construction parameters are rather complex in their shape:

1. Yarns' diameters are uniform cylinders.

2. Warp spacing at the weave intersection and under the float is constant.

3. Pick spacing at the weave intersection and under the float is constant.

4. The projection (two-dimensional) of the fabric on a plane parallel to fabric plane is considered.

5. Yarns' are uniformly colored/weaves.

The resultant proportions of colors/weaves present on the surface of the woven design are calculated for the repeat that represents an entire region in the Jacquard design. 


\subsection{Crinkles Potential of Wefts in Shape Square}

In differential geometry, deformations from the wefts on a surface are considered as a series of twisted curves which generate into a three-dimensional shape in figure6. This theory is applicable to the surface of the material in fabric buckling, folding and drape. The differential geometry parameters can incorporate the mechanical properties of a material by relating these mechanical properties to the changes in curvature as a surface is transformed into another surface. And compact forces of deformation on square shape:

$$
\mathrm{CD}=\sqrt{\frac{\mathrm{SP} \%}{\mathrm{C} \mathrm{W} \mathrm{R} / \mathrm{mm}}}+\frac{w a r p+W R}{W R} \%
$$

Where: CD: Crinkles Distortion, ST\%: stretch potential \%, CWR: crinkles width repeat $/ \mathrm{mm}$., and WR: Weft Repeat, we believe that the numerical integration method is a better approach because surface area is the double integration of surface for the two layers of fabrics coordinates, which acts as low layer while changing with height layer out deformations. Surface areas between the double-layers and compact force of stretch of weft and wove structures. For better approximation, the following formula which takes layers of woven fabrics, namely:

$$
\begin{aligned}
& \text { Warp Float Distortion }=\frac{\text { weft contraction for each float }}{\text { the warp float length }} \times 100 \\
& \mathrm{~S}_{\mathrm{D}}=100 \pi \frac{\omega \int}{4}+\frac{W F D}{S P_{W}}\left[\int \frac{K_{C}+\sum\left(h_{y}+h_{w}\right)}{4 T_{T K}}+\frac{(\rho \mathrm{y})}{(\rho \mathrm{f})}\right]
\end{aligned}
$$

Where: $S_{k}=$ shape Deformation. $W F D=$ Warp Floated Distortion. ${ }^{T_{T K}}=$ fabric thickness. $S P$, max $=$ Stretch potential. ${ }^{\omega}=$ width of shape. $\int^{\int}=$ length of shape. $K_{C}=$ cloth cover factor. ${ }^{\rho y}=$ yarn density. $\rho \mathrm{f}=$ fiber density., $\left(h_{y}+h_{w}\right)$

Where: $L(h)$ is the parameter of a cross sectional curve at level $h$ and $h_{2}$ are the "height" of the bottom, middle and top cross section, respectively. The perimeter is the sum of point-topoint distance (chord length).

In order to minimize the choices that had to be made, and to streamline the process, a couple of specific conventions have been built into the software: - Of the two stitch lines that make up the edges of a given panel, the stitch line with the lower number is deemed to be the left-hand side of the panel. - Each stitch type is deemed to run in a particular direction: horizontal stitch s run left-to-right, vertical stitch s run top-to-bottom, right diagonal stitch s run from top left to bottom right, left diagonal Stitch s run from bottom left to top right, and geodesic stitch run in the direction in which they were created.

Let us examine what these conventions actually mean, and what affect they have on the actual panel-creation process. Consider the tent portion below: tent portion with stitch $\mathrm{s}$ defined on it, the dark lines represent the Stitch $\mathrm{s}$. When surface calculates the panels defined by this stitch (1) is deemed to be the left-hand side of the panel, and stitch 2 the right-hand side. Next, it is necessary to find the start points of the stitch.

The fundamentals of the geometric assumptions of the computer program are shown in Fig. 10 (a), (b) and (c).

As will be seen in Fig. 9 (b):

IRTIIIE Vol. 4, No. 1, 2016 ISSN 1314-8788 (print), ISSN 1314-8796 (online), doi: 10.15547/artte.2016.01.006 
It can be detrained. So:

$$
\mathrm{L}_{\mathrm{n} / 2}=\left(\frac{\operatorname{sine} \alpha \sqrt{\left(L_{o} / 2\right)^{2}+D^{2}}}{D}\right) D / L_{o / 2}
$$

$$
\left(\frac{\frac{j}{N / 2}}{\frac{\boldsymbol{l}_{o j}}{\boldsymbol{L}_{o / 2}}}\right)-\left(\sqrt{\frac{j}{N}}\right)+\frac{2 j+\boldsymbol{I}_{j}}{N}
$$

$j:$ The sequence of any warp yarn, $l_{o j}$ : The initial length of any one of the warp yarns

$l_{j}$ : The length of any one of the warp yarns after deformation, and N/2

Figure 9: geometric assumptions forming the fundamentals of the computer programs (a) Distribution of the pressing force, (b) Position at the perpendicular cross-section after deformation: $L O=2$ : The length until the middle point of the frame side , $L n=2$ : The length of the yarn until the middle point of the frame side after deformation , (c) Comparison between before and after deformation (Top view) The all results in a panel as below:

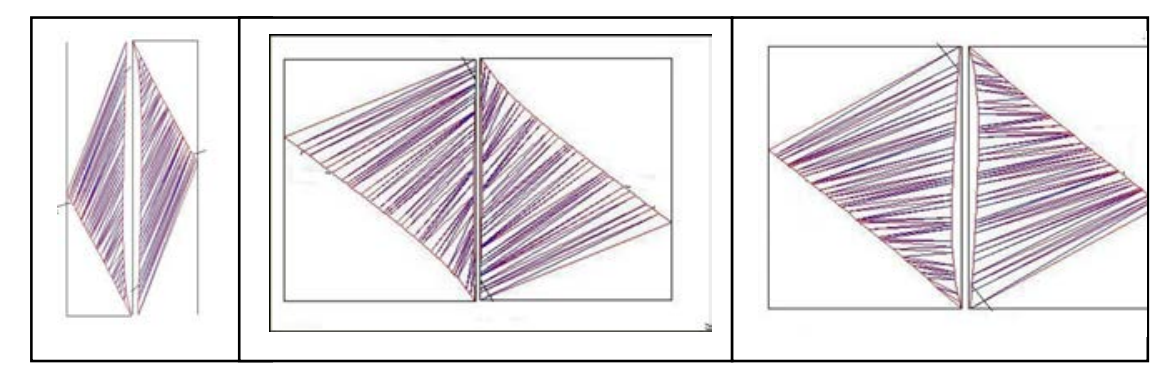

Figure 9. Panel produced from the tent region between stitch 4 and 5

Similarly, the second panel (between stitch s 2 and 3) has stitch 2 on the left-hand side, stitch three on the right-hand side, and has the start points of the Stitch $s$ at the bottom of the panel, and the panel produced from the tent region between stitch 2 and 3 .

\subsection{Geometry of the relaxation behavior}

As the free spaces (voids) increase, the freedom of movement for the yarns goes higher in Figure 3. In other words, the firmness of the fabric reduces. Comparison of the three woven fabrics by using different materials is shown in Table1. The weave factor and shrinkage factor are calculated according to equations 5 and 6.

\subsubsection{Calculation Warp Float Distortion}

$$
\text { WFDe }=\frac{\text { WCEF }}{\text { WFL }} \times 100
$$

WFDe: Warps float Distortion, WCEF: weft construction for each float, WFL; the warp float length.

Warp degree of movement of the 1/1 plain weave, satin and spider weave. The angle in which the weft float will migrate (the weft plane movement) is: warp float migration $(\mathrm{mm})$ : The movement of the warp float is related to the amount of weft contraction. In other words, warp float migration is the weft contraction per each warp. The maximum possible movement of the warp float is equal to $(5 \mathrm{~mm} / 27)$. Therefore, there is no migration and movement for the weft float is related to the amount of warp contraction by using the spandex throw crinkles

IRTTIE Vol. 4, No. 1, 2016 ISSN 1314-8788 (print), ISSN 1314-8796 (online), doi: 10.15547/artte.2016.01.006 


\section{IRTIIE

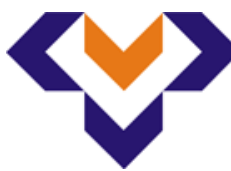 \\ Ipplied Reseirldhes in Technics, Technologies and Bductation \\ Journal of the Faculty of Technics and Technologies, Trakia University https://sites.google.com/a/trakia-uni.bg/artte/}

effects: 1 - Fabric Structures; 2 - Type of materials (Normal, Containing Spandex...); 3 Types of Multi-Layer Woven Fabrics; 4 - Stitching methods of multilayer woven fabrics; 5 Length of yarn floated; 6 - Processor Thermal on Fabrics (Wet, Dray); 7 - Chemical processors on Fabrics; 8 - Thickness of fabrics; 9 - Shape of Three-Dimensional.

\subsubsection{The Relationship of Crinkles Potential with Using Double-Layer Woven Fabrics}

It has been found that there is a clear relationship between of crinkles Potential with using double-layer woven fabrics, where it has been used in different woven fabric structures:

A. First woven fabric structure, is plain woven $1 / 1$, for face and back "the repetition woven fabric structure of warp yarns and weft. It was found that there are some samples achieved a higher crinkles Potential than others, including samples from 1 to 8 , which include fourth type stitched , and fifth type of stitched, also sample No. 8 gave higher crinkles potential, resulting from the use of the addition extra warp.

B. Second woven fabric structure, which is the very fabric of facial spider for face fabrics, plain woven 1/1, for back fabrics, and yarn repeat, and wefts were found that samples had achieved a higher inflation and samples produced using methods of stitched fourth and fifth, compare first woven fabric structures (plain woven $1 / 1$ for face and back) with combination second woven fabric structures (spider weave for face, plain weave 1/1 for back) from where crinkles effects was found that the composition of the second woven fabric for given a clearer structure of crinkles effects more than the first woven fabric, due to the use of the very fabric of spider as well as increase the high repetition woven fabric in combination second woven fabric in the composition of the first woven fabric of $1 / 1$ for face and back.

\subsubsection{Crinkles potential and type of material}

In double-layers woven fabrics, There is a clear relationship between the crinkles potential and type of material in double-layers woven fabrics, it was found that when using spandex as wefts in fabrics combinations of research resulted in an crinkles effects did not appear clear that when using a weft of cotton in the samples, also found that spandex as weftscored of blended cotton plus the polyester 50\% : 50\% gave clear results of crinkles effects in all types of stitches in combination of first and second examples of these samples in comparison to covered spandex.

\subsubsection{The Relationship between type of stitches and Crinkles potential}

There is a clear relationship between crinkles effects and the number of layers, using dual fabrics and woven fabrics in different woven structures got as much of crinkles potential cannot be obtained in the single fabrics, this crinkles potential could increase with the use of other variables as a stitches between the two layers or different woven fabrics structures use various of wefts. The relationship between crinkles potential and type of stitches between double layer woven fabrics, there is a clear relationship between the crinkles potential and type of stitches in between double layer woven fabrics it has achieved certain types of stitches, of inflation and other types of stitches, which achieved a clear fourth type of stitches and interlacing threads overlap with and fifth type of stitches and interlacing threads.

\subsubsection{Construction Repeats}

The fabric repeat angle is the sum of the warp and weft repeat angles. In other words, the fabric repeat is the degree of the warp and weft float distortion, based upon the above theoretical suggested estimation, the maximum possible repeats for each fabric is calculated and the values are compared with the actual measured repeats. This equation gives us more

IRTIIE Vol. 4, No. 1, 2016 ISSN 1314-8788 (print), ISSN 1314-8796 (online), doi: 10.15547/artte.2016.01.006 
fitting results especially to calculate the crinkle woven fabrics in garments. This model was constructed to have a geometry complicated enough to see the effect of changing the medium location but simple enough to save computational time by using the equation (11, 12, 13). So we had established new equation for calculation the crinkle distortion:

$$
\mathrm{CD}=\sqrt{\frac{\mathrm{SP} \%}{\mathrm{CWR} / \mathrm{mm}}}+\frac{W D e+W f R}{W f R} \%
$$

CD - crinkles distortion, SP - stretch potential, CWR - crinkles width repeat, WDe - warp density of ends.

$$
\text { Yarn } / \mathrm{cmm}=\frac{\text { Warp Threads }}{\text { Width of Crinkel Fabrics }}
$$

For calculating yarn per centimeter as: Then must be used new equation for calculation a length (L) of crinkle woven fabrics.

\subsection{Calculation a length (L) of crinkle woven fabrics}

$$
\mathrm{CL}=\frac{\pi\left(d_{2}+d_{2}\right)}{\mathrm{CD} \sqrt{d_{2}{ }^{2}+2 d_{1} d_{2}}}+(\pi \psi-\Omega) \cos ^{-1} \frac{d_{1}}{d_{1}+d_{2}}-1 * 10
$$

Where; CD; crinkles distortion, CL; crinkle length, $\ell$;crinkle length $(\mathrm{mm}), \Omega$ is crinkle width $(\mathrm{mm}), \psi$ is crinkle height $(\mathrm{mm})$, as example for calculation crinkle length of sample 1 as the following to:

$$
\begin{gathered}
\text { Crinkle length }=\frac{3.14(0.0239+0.0239)}{180 \sqrt{(0.0239)^{2}+2(0.0195) * 0.0239}}+(3.14 * 2.36-4) \cos ^{-1} \frac{0.0195}{0.0195+0.0239}-1 * 10 \\
\mathrm{D} W=\mathrm{DW} \text { per } \mathrm{cm} . \times \mathrm{Wd}
\end{gathered}
$$

DW - Density of Warp, Wd - Width of Warp .

$$
\mathrm{RPW}=\frac{\mathrm{DW}}{\mathrm{YR}}
$$

RPW - Repeated of plain weave, YR - yarn repeated. Warp threads $=27 * 162=4374$ yarns; Repeats of Plain weave $=4374 / 2=2187$; Repeats of on Based twill weave $=4374 / 12=364.5$; Repeats of Spider weave $=4374 / 48=91.125$.

\subsection{Aesthetics Distortion of the Crinkles potential}

We can get the aesthetics crinkle fabrics by distortion structure of woven fabrics, due to the structural symmetry as repeats of a crinkles potential woven fabrics and the unit cell is considered as the one quarter of spider crinkle woven fabric. The yarns are represented as homogenous cylinders of constant diameter, with initially restricted contact area between them. We consider orthotropic structure properties of the spandex yarn with three levels of crinkle woven fabrics modules, one for the yarn axis direction, and one for the yarn radius direction as Figure 9. The levels of crinkle woven fabrics allow the unit cell of deformation as distortion structure considered as being positioned in the center of the specimen. Simulation of the structure test of a of a crinkle woven fabrics as it is executed at the main purpose of this distortion structure for crinkle unit is the creation of a model of the crinkle woven fabrics

IRTIIIE Vol. 4, No. 1, 2016 ISSN 1314-8788 (print), ISSN 1314-8796 (online), doi: 10.15547/artte.2016.01.006 


\section{IR'TIE

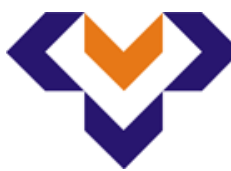 \\ Ipplied Reseirldhes in Technics, Technologies and Bductation \\ Journal of the Faculty of Technics and Technologies, Trakia University https://sites.google.com/a/trakia-uni.bg/artte/}

structure via Photoshop software programming and use of the $3 \mathrm{D}$ visualization of the structure. This method supports the better understanding of the deformation process of the yarns crinkle due to the applied distortion structure in the fabrics, by the superposition of three deformation modes (height, medium, graven) levels, figure 4. With three woven fabric structures, which correspond in the distortion structure, these three regions cannot be distinguished and are accompanied by the yarn slippage and the compression deformation of distortion structure by spandex weft at the link points of the crinkle woven fabrics. Especially at spider weave condition, that is the zone of the main interest, the dominating mechanism of deformation is the change of the crinkles potential woven fabrics shape due to the distortion structure of the yarns in woven fabrics. Under these conditions, the shaped arcs of the crinkle cell have a significant influence in the deformation process of distortion structure. Since the mechanical loading of the yarns imposes increase of the contact area with essential local deformations and distortion structure. The satisfactorily fitting of the theoretical curves to the experimental ones ensures the accuracy of the geometrical characteristics that are used for the modelling; all parameters of distortion for crinkle woven fabrics structure mentioned above were calculated for all crinkle woven fabrics. The specific volume is significantly influenced by behavior of the spandex filling spaces in between structural characteristics values of porosity and rephrases fabrics in figure 4 and their deviations from experimental crinkle woven fabrics values after bleaching. In open structure fabrics the suggested method gives relatively good results.

In-Plain movement: This portion of the spandex yarn, in one hand is shrinkage and causing to bring the crossing yarn closer to each other and the shrinkage forces of the crossing cotton yarns effect clamping itself tighter on the other hand. The shrinkage forces acting on the Interlacing parts of the spandex yarn are opposite to each other and act against the inplane float movement. However, the distortions resultant quantity of the moment is relatively low due to the short length of the cotton yarn and lower freedom to migrate. The second movement is in the direction perpendicular to the plane of the fabric, in the thickness direction of the fabric and does not have a direct effect on in plane movement of the floats.

In-Satin movement: This portion of the spandex weft, in one hand is shrinkage and causing to bring the crossing warp cotton yarn, more closer to each other and clamping itself tighter in Satin weave and on the other hand is rephrase by the shrinkage forces of the crossing warp cotton yarns. The shrinkage forces acting on the interlacing parts of the warp cotton yarn are opposite to each other and act realizing the in- Satin float movement. However, the distortions resultant quantity of the movement is relatively high due to the longer length of the warp cotton yarn and lower freedom to migrate. The second movement is in the direction perpendicular to the satin of the distortions fabric, in the thickness direction of the fabric, and has direct effects distortions crinkles on in satin movement of the floats while fabrics thickness go up.

In-Spider movement: This portion of the spandex yarn, in one hand is shrinkage causing to bring the crossing warp yarn closer to each other and clamping itself tighter in spider weave and on the other hand is affected distortions by the shrinkage of the crossing warp cotton yarns. The shrinkage forces acting on the interlacing parts of the warp cotton yarn are closer to each other and more act realizing the in-spider float movement. However, the results of distortions quantity by the yarns of warp migration are high relatively due to the short length of spandex. The second movement is in the direction perpendicular to the spider of the fabric in the thickness direction of rephrase on in-spider movement of the floats. Total movements acting on each yarn in one repeat is the sum of the forces acting on floats making the floats to distortions crinkles and movements acting on the interlacing portion of spandex weft, therefore, effective movement is related to the characteristic of spandex to contract and its distortions surface character, the weaving conditions especially the spider weaving tension, and the fabric structures the lower the weave factor, the higher the freedom to migrate.

\section{IRTTIE Vol. 4, No. 1, 2016 ISSN 1314-8788 (print), ISSN 1314-8796 (online), doi: 10.15547/artte.2016.01.006}




\section{ART'TE $Y$}

Ipplied Researleches in Technics, Technologies and Bdurition

Journal of the Faculty of Technics and Technologies, Trakia University https://sites.google.com/a/trakia-uni.bg/artte/

Location of the Free Spaces: The location of the free spaces assigned the direction of the float movement. Indeed, the location of the free spaces on either side of the float offered a free way of assigning the direction in which the float in plane is distortion crinkles. Twill have free interlacing zone on right side of the top part and left side of the bottom part of the cotton warp floats offering the warp floats to turn crinklewise. So twill weave have free interlacing zones located on left side of the top part and right side of the bottom part of the cotton warp floats to let them crinkles counter crinklewise, so spider weave has free interlacing zones on warp cotton located on left side of the top part and spandex right side of the bottom part of the yarns floats to let them crinkles potential counter crinklewise of horizontal direction. It causes less air permeability while fabrics crinkle go up.

The Float Length: As the float cotton yarns length gets longer the freedom of the float contacts get higher. The comparisons of $1 / 1$ plain weave to satin and spider weave in Table 2 shows a direct relationship between the locations of the free spaces assigned the direction of the float movement. Indeed, the location of the free spaces on either side of the float offered a free way of assigning the direction in which the float an in plane could crinkle. Satin weave has free zone on spandex right side of the top part and left side of the bottom part of the warp floats to turn crinklewise. Left hand stains have free zones located on left side of the top part and right side of the bottom part of the warp floats to let them crinkles potential counter crinklewise.

Shrinkage: comparing fabric tightness (weave), plain weave showed lower shrinkage after wet processing as compared to stain and spider weave at same crinkle distortion, stretch potential. This shows that plain weave is more stable than on based stain and spider weave. This is because plain weave started with lower stretch potential due to tight construction and does not have enough margins for distortion. However, in both weave types, shrinkage reduced with further wet processing. It was obvious from the results that irrespective of spandex type, fabrics containing spandex do retract/expand after treatment. The $\%$ retraction needs to be determined and accounted for to get to rephrase.

\section{SUMMARY AND CONCLUSIONS}

The purpose of this study was to establish crinkles potential the dependences between the constructional parameters of double woven fabrics, namely type of weave and the method of stitching, and following mechanical properties: breaking strength and elongation, tearing strength, wrinkle recovery and fabric stiffness. The results of analysis of variance clearly indicate that the method of stitching doesn't have statistically important effect level on the upper mentioned mechanical properties, except for the tearing strength in warp direction and fabric stiffness. The influence of type of weave is much more evident regarding the mechanical properties. All mentioned mechanical properties are influenced by weave, except wrinkle recovery.

\section{REFERENCES}

[1] AATCC (1968), "D-79-1968" - Standard Test Method.

[2] ASTM (2008), "D 1388" - Standard Test Method for Stiffness of Fabrics.

[3] ASTM (2015), "D 3885-07a" - Standard Test Method for Abrasion Resistance of Textile Fabrics (Flexing and Abrasion Method).

[4] ASTM (2004), "D 3885" - Standard Test Method for Abrasion Resistance of Textile Fabrics (Flexing and Abrasion Method).

[5] ASTM (2012), "D 6603-10" - Standard Guides for Labeling of UV- Protective Textiles.

[6] ASTM (2007), "D1777-96" - Standard Test Method for Thickness of Textile Materials.

[7] ASTM (2013), "D3776/ D3776M-09a" - Standard Test Method for Mass per unit area (weight) of Fabric.

IRTTIE Vol. 4, No. 1, 2016 ISSN 1314-8788 (print), ISSN 1314-8796 (online), doi: 10.15547/artte.2016.01.006 


\section{AR'TIE

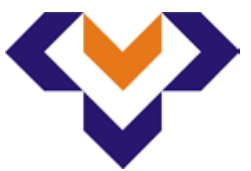 \\ Ipplied Researleches in Technics, Technologies and Bdurition \\ Journal of the Faculty of Technics and Technologies, Trakia University https://sites.google.com/a/trakia-uni.bg/artte/}

[8] ASTM (2008), "D5035-06" - Standard Test Method for Breaking Force and Elongation of Textile Fabrics (Strip Method).

[9] ASTM (2008), "D737-04" - Standard Test Method for Air Permeability of Textile Fabrics.

[10] Chen M., Sun Q., Wu Z., Yuen M. (1999), A Discretized Linear Elastic Model for Cloth Buckling and Drape. Journal of Manufacturing Science and Engineering, 121 (11).

[11] D.Riedel, (1986), "International Textile Bulletin", vol. 32, p.17.

[12] E.R.Kaswell, (1983), Wellington Sears Handbook of Industrial Textiles, Wellington Sears Company Inc., p.455.

[13] Elnashar, E. A. (1995), Effect of Warp-ends Densities Distribution on Some Esthetical and Physical Properties of Multi-layer Woven Fabrics, MSc Thesis, and Faculty of Applied Arts. Helwan University Egypt.

[14] EINashar E. A., (2014), Compact force using rough set theory of geometry shape for stretch clothes design, Applied Researches in Technics, Technologies and Education, Vol. 2, No. 2, 2014, ISSN 1314-8788 (print), ISSN 1314-8796 (online).

[15] Elnashar E. A., Polona D. Dubrovskil, (2005), The influence of weave and the method of stitching on some mechanical properties of woven double fabrics, $5^{\text {th }}$ World Textile Conference AUTEX 2005, 27-29 June 2005, Portorož, Slovenia.

[16] Elnashar E. A., Polona D. Dubrovski (2008), The influence of the weave and the method of stitching on selected mechanical properties of woven double fabrics, AUTEX Research Journal, Vol. 8, No 2.

[17] Elnashar E. A. (2012), Compact force using rough set theory of geometry shape for stretch clothes design, Smartex-2012, the XI International Workshop "Physics of Fibrous Materials: Structure, Properties, Science Intensive Technologies and Materials, "SmarTex-2012", the Ivanovo State Textile Academy from 28 - 29 May, 2012, Russia.

[18] EINashar E. A., Galina Bashkova, (2014), Comfort of thermal insulatiuon of bulky woven fabrics for clothes. International Conference on Technics, Technologies and Education ICTTE 2014 October 30-31 2014, Proceedings CD, ISSN 1314-9474, Faculty of Technics and Technologies of Yambol, Trakia University. Bulgaria.

[19] EINashar E. A., Fatma Kalaoglu, Mohamed Hashem. (2010), Crinkles Approach for Development of Aesthetics Wrinkled Fabrics Containing Spandex, XIII International Workshop "Physics of Fibrous Materials: Structure, Properties, Science Intensive Technologies and Materials" (SMARTEX-2010), Ivanovo, Russia, 24-26 May 2010.

[20] Fangning S., Seyam A., Gupta B. (1997), A Generalized Model for Predicting LoadExtension Properties of Woven Fabrics". Textile Research Journal, Vol. 67, No. 12, 866874.

[21] Jong S., Postle R. (1978), A General Energy Analysis of Fabric Mechanics Using Optimal Control Theory. Textile Research Journal, Vol. 48, 127-135.

[22] Kavita Mathur, ElSayed EINashar, Peter J. Hauser, and Abdel-Fattah M. Seyam. (2008), Stretch potential of woven fabrics containing spandex, The 5th International Conference of Textile Research Division, National Research Center Cairo, Egypt, April 6-8 2008.

[23] M. Rowe. (1978), Textile Chemistry and Colorist. p. 10-207.

[24] Realff M. L., Boyce M. C., Backer S. (1997), A Micromechanical Model of the Tensile Behaviour of Woven Fabric. Textile Research Journal, Vol.67, No.6, 445-459.

[25] Shanahan W., Lloyd D. W., Hearle J. W. S. (1978), Characterizing the Elastic Behaviour of Textile Fabrics in Complex Deformations. Textile Research Journal, Vol.48, 495-505.

[26] Sinoimeri A., Drean J. W. (1997), Mechanical Behaviour of the Plain Weave Structure Using Energy Methods. Textile Research Journal, Vol. 67, No. 5, 370-378. 